\title{
Physical Limnology in Lake Banyoles
}

\author{
Xavier Casamitjana, Jordi Colomer, Elena Roget and Teresa Serra \\ Environmental Physics Group i Institut de Medi Ambient. Campus de Montilivi. Universitat de Girona. \\ 17071-Girona. Spain \\ Corresponding author: xavier.casamitjana@udg.es
}

\begin{abstract}
The main physical long-scale processes occurring in Lake Banyoles are reviewed as a tribute to Prof. Margalef. These processes include the water fluxes below the surface of the lake, the behavior of the sediment in suspension in the basins, the heat fluxes at the surface and at the bottom layers, the internal seiching, the formation of a baroclinic current due to differences in cooling between the two lobes, the mixing dynamics, the meromictic behavior of some of the basins and the formation and dynamics of hydrothermal plumes
\end{abstract}

Keywords: physical processes, sediment in suspension, internal seiches, baroclinic currents, hydrothermal plumes

\section{RESUMEN}

Los principales procesos fisicos de gran escala que tienen lugar en le Lago de Banyotes son revisados como tributo al Profesor Margalef. Estos procesos incluyen los flujos de agua bajo la superficie del lago, el comportamiento del sedimento en suspensión en las cubetas, los flujos de calor en la superficie y en el fondo, las secas internas y la formación de corrientes baroclínicas debido a la diferencia de enfriamiento entre los dos lóbulos, la dinámica de mezcla, el comportamiento meromictico de algunas de las cubetas y la formación y dinámica de las plumas hidrotérmicas.

Palabras clave: procesos físicos, sedimento en suspensión, secas internas, corrientes baroclínicas, plumas hidrotérmicas.

\section{INTRODUCTION}

It was about 1985 when two of the authors of this paper and their future $\mathrm{PhD}$ supervisors (David Jou and Josep Enric Llebot) visited Prof. Margalef in his office at the Ecology Department of the University of Barcelona. The authors wanted to focus their studies on the physical processes occurring in Lake Banyoles and, knowing of Prof. Margalef's scientific interest in the lake, asked him for his advice. The pioneering work of Prof. Margalef in Lake Banyoles (Margalef, 1946), had been followed by various studies on the ecology of the lake (Planas, 1973; Guerrero et al., 1978; Rieradevall \& Prat, 1991), but very little was known about the physical processes there. Prof. Margalef was always encouraging researchers with background in physics to undertake a study of the subject. After long and fruitful discussions, we decided to approach
Lake Banyoles by studying the hydrodynamics of the lake. In 1992, when Prof. Margalef came to Girona as a member of the committee evaluating one of these PhDs, he let us know that he agreed with our approach and encouraged us to pursue physical limnology further. Since then, many other research studies undertaken by the Environmental Physics Group of the University of Girona have been related to the lake, and the $\mathrm{PhD}$ theses of the other two authors of this article were also related with Lake Banyoles.

Although nowadays the focus of the Environmental Physics Group has been broadened to cover other fields such as reservoirs, wetlands and oceans (Serra et al., 2003; Roget et al., 2005), there are still two PhD theses being written about different aspects of Lake Banyoles, from which some preliminary results are referred to in this paper. The complexity of the lake's hydrodynamics, together with recently develo- 
ped instruments, such as microstructure sensors, acoustic Doppler current meters, particle size analyzers, etc., make these new studies seem as passionate as those in the beginning. Going back to 20 years ago, we can't avoid thinking in the first pioneering researches of Lake Banyoles. Although some of those papers, written in Catalan or Spanish, will not be of interest to an international audience, they might be for local researchers; the same applies to some of our first works which have never been published in English and are reviewed in this paper.

Today we are pleased to review the history of hydrodynamic studies in Lake Banyoles as a tribute to Prof. Margalef. The main physical processes to be reviewed here are schematised in figure 1 and include the water fluxes below the surface of the lake, the behaviour of the sediment in suspension in the basins, the heat fluxes at the surface and at the bottom layers, the internal seiching, the formation of a baroclinic current due to differences in cooling between the two lobes, the mixing dynamics, the meromictic behaviour of some of the basins, and the formation and dynamics of hydrothermal plumes.

\section{THE SUBTERRANEAN SPRINGS OF THE LAKE}

Lake Banyoles, located in the eastern Catalan pre-Pyrenees $\left(42^{\circ} 07^{\prime} \mathrm{N}, 2^{\circ} 45^{\prime} \mathrm{E}\right)$, is a small multi-basin lake of mixed tectonic-karstic origin with a surface area of $1.12 \mathrm{~km}^{2}$ (Fig. 2). The tectonic constraint of the lake forces the groundwater flow through the bottom of the basins in a vertical discharge (Moreno \& García-Berthou, 1989). The subterranean springs keep several meters of sediment in suspension at the bottom of the conic inflow areas and up to a fairly sharp sediment interface, known as the lutocline, where the particle concentration can vary from about $180 \mathrm{mg} / 1$ to less than $1 \mathrm{mg} / \mathrm{l}$. The suspended sediment is formed by a mixture of marly and argillaceous materials and they have a nearly constant temperature throughout the year $\left(19^{\circ} \mathrm{C}\right)$, being 2$3{ }^{\circ} \mathrm{C}$ higher that that of the hypolimnetic water in summer and $8-10^{\circ} \mathrm{C}$ higher in winter. Subterranean water inflow is also saltier than the bulk water of the lake (Casamitjana, 1989).

The importance of the underground inflow to the lake's dynamics did not escape the first re-

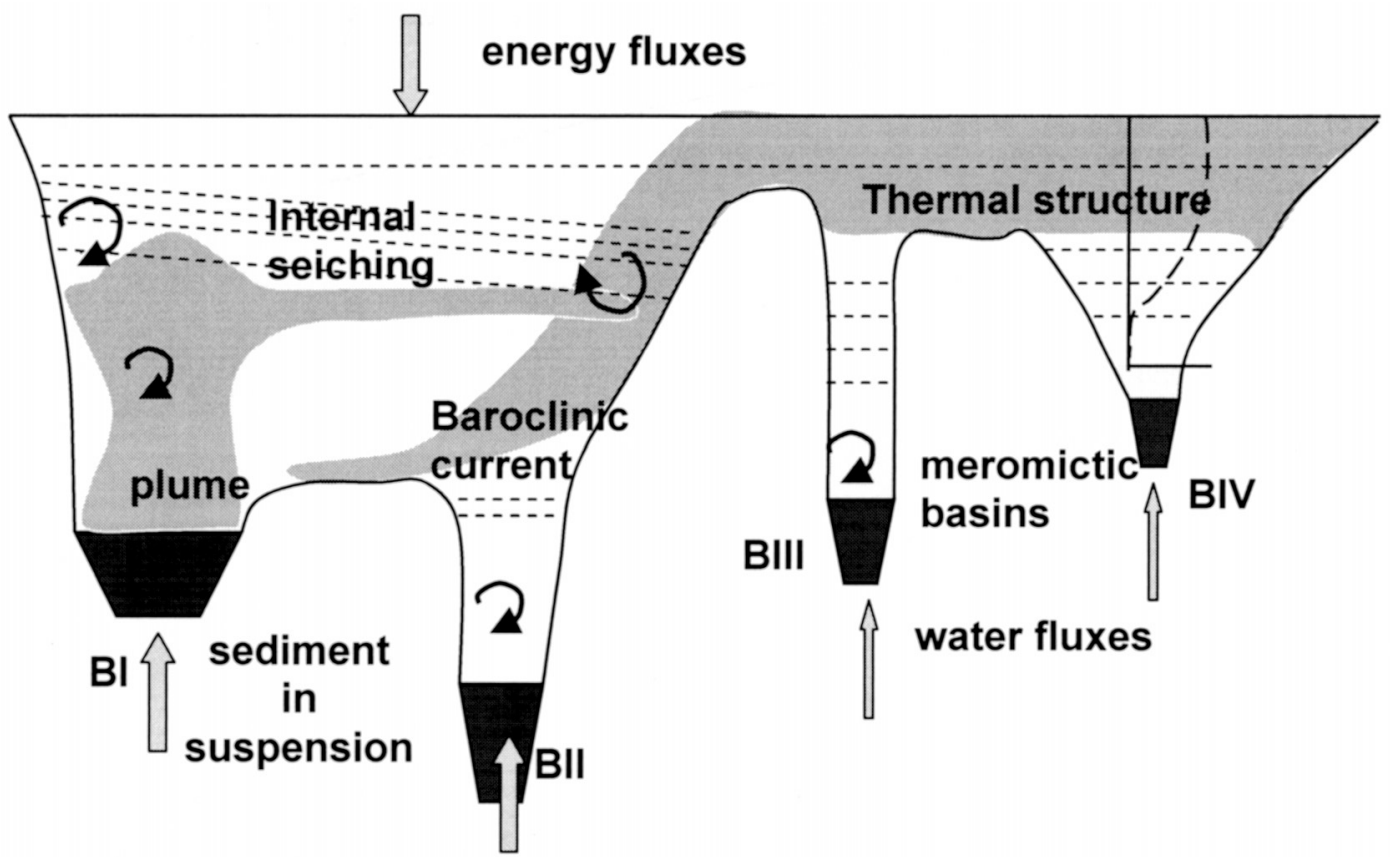

Figure 1: Scheme of the main physical processes occurring in Lake Banyoles. Esquema de los principales procesos fisicos que tienen lugar en el Lago de Banyoles. 
searchers studying the lake. Calculations based on the difference between the surface inflows and outflows had already been done 80 years ago, estimating a global underground inflow of around 600 1/s (Mascaró, 1914; Vidal-Pardal, 1925). However, the global estimations did not account for the different physical, chemical, and biological properties of the basins (Guerrero et al., 1978). The groundwater inflow within the individual basins was first determined in 1986 based on measurements of the settling velocity of the particles in the suspensions, their porosity and the cross sectional area (Roget, 1987; Roget et al., 1994). The most important conclusion from this study was the location of the main underground inflow in the southern lobe (BI in Fig. 2), which usually supplies around $85 \%$ of the total incoming water by subterranean springs. Casamitjana et al. (1988) calculated the heat flux from the basins of Lake Banyoles and estimated that, if the lake were not heated from below, the heat budget would increase by around $6.710^{7} \mathrm{~J} \mathrm{~m}^{-2}$ over $7.910^{7} \mathrm{~J} \mathrm{~m}^{-2}$. They also estimated that the heat through BI was $90 \%$ of the total underground heat coming into the lake.

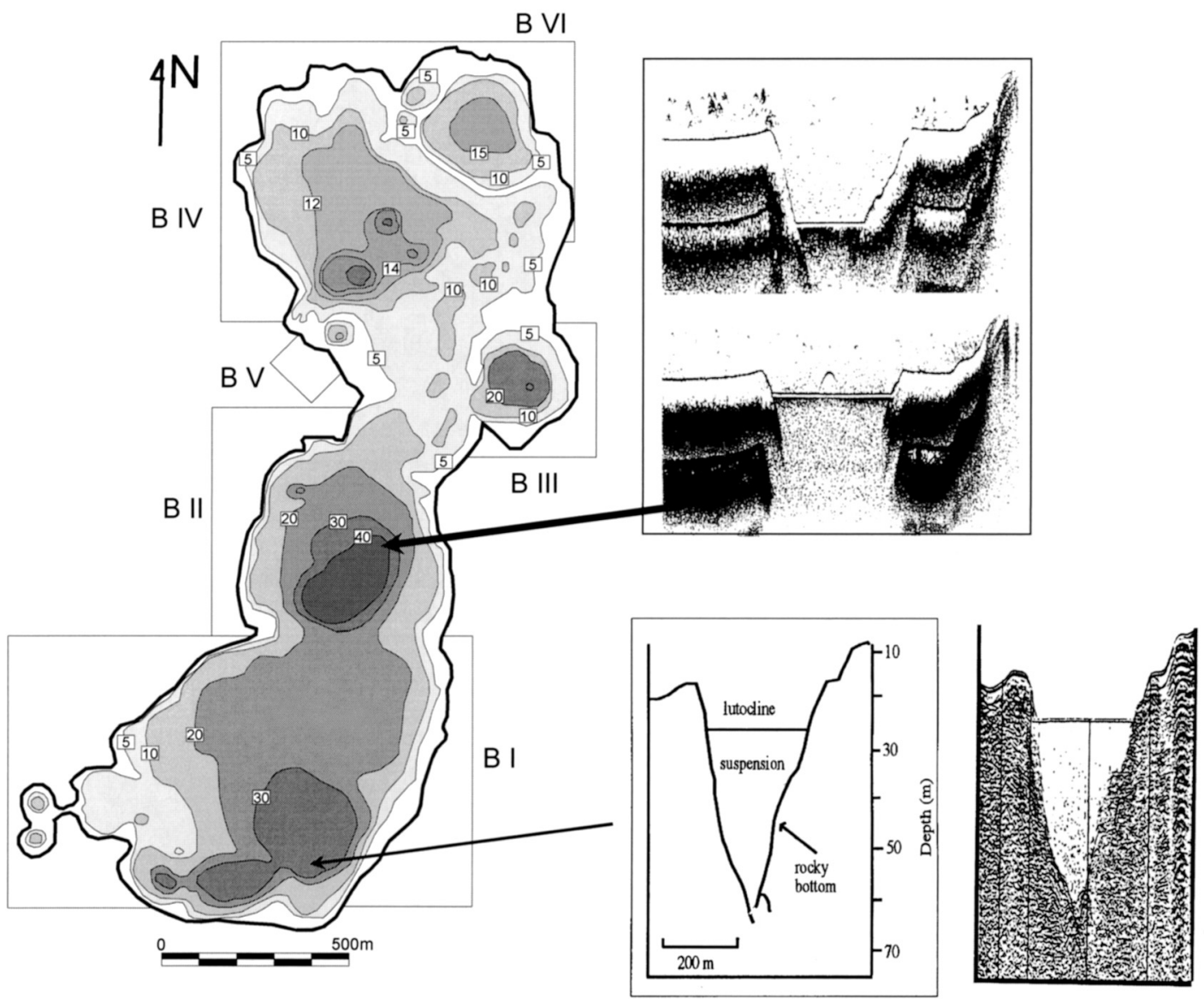

Figure 2. Bathymetric map of Lake Banyoles. Depth contours are in meters. The lake is composed of six basins (BI to BVI). The bottom right panel shows a schematic view of basin I of Lake Banyoles (BI) obtained from a seismic profile and its interpretative section (adapted from Canals et al. 1990). The top right panel shows two echosounding profiles of basin BII for two different recharge volumes. Sediment in suspension is clearly delimited by an horizontal interface. Mapa batimétrico del lago de Banyoles. Los contornos de profundidad están en metros. El lago está formado por 6 cubetas. El panel de la parte inferior derecha es una representación esquemática de la cubeta I del Lago de Banyoles (BI), obtenida mediante perfiles sismicos, juntamente con un esquema interpretativo (adaptado de Canals et al. 1990). El panel de la parte superior derecha muestra dos perfiles de ecosonda de la cubeta BII, para dos flujos diferentes de entrada. El sedimento en suspensión está claramente delimitado por una interfase horizontal. 
Different laboratory studies were carried out in order to simulate the re-suspension of particles by a flow from below. Roget \& Casamitjana (1987) used a glass column $140 \mathrm{~cm}$ high and $10 \mathrm{~cm}$ in diameter with a variable water supply at its bottom and extraction points every $10 \mathrm{~cm}$ along the column to study the fluidisation process. Casamitjana \& Roget (1990a) also stated the importance of the history of the bed on its departure for the ideal behaviour. Laboratory studies were also performed by Colomer \& Fernando (1996) using a tank with a jet nozzle located at the centre of the bottom, beneath the particle layer. The jet, carrying fluidised particles, penetrated through the particle bed and emanated into the upper layer. They identified two different flow regimes. The first one, called the "continuous re-entrainment" regime, occurring at low values of momentum fluxes, is characterized by no significant deposition of particles from the particle-laden jet onto the bed. In the second one, called the "full deposition" regime, the particles that were initially entrained into the jet were found to deposit back onto the bed with time, thus forming an axisymmetric particle mound around the inlet jet.

Casamitjana et al. (2000) carried out a similar experiment but using a conical basin. They identified two regimes: the so-called "jet flow" and "lutocline flow" regimes; the "full deposition" regime was not found here. In the "lutocline flow regime", the particles were re-suspended forming a well-established interface along the entire cross sectional area of the cone. The maximum height to which particles can rise was found to depend on the momentum jet, the initial height of the particle bed, the particle diameter, the Reynolds number of the particle, and the slope of the conical basin. Results obtained in this experiment show good agreement to what was observed in Lake Banyoles, provided that the sediment particles aggregate within the suspension.

Particle size distributions of the suspended sediments in Lake Banyoles have repeatedly been obtained by different methods (Sanz, 1985; Roget, 1987). However, the handling and analysing procedures may disrupt the suspended aggregates, altering the results. To measure the "real" diameter of the suspended particles, samples of sediment were immediately frozen in situ by introducing them into liquid nitrogen containers (Casamitjana et al., 1996). From the frozen sediment, samples were taken and deposited on a nucleopore membrane and then analysed by a scanning electron microscope. This technique showed mean diameters of around $60 \mu \mathrm{m}$, which reveal good agreement with the experiments carried out by Casamitjana et al. (1996).

The re-suspension of sediments and the formation of the lutoclines can be also simulated by using a two-dimensional $\kappa-\varepsilon$ model (Colomer et al., 1998). The results of the model predict a re-circulation zone below the lutocline and a severe damping of the turbulent kinetic energy and effective viscosity at the bottom of the lutocline due to the buoyancy flux. The lutocline acts as a barrier to the propagation of the turbulent kinetic energy. However, due to the convective processes generated immediately above this interface, there is a local increase of the rate of turbulent kinetic energy dissipation (Muñiz, 2000; Sánchez, 2001; Lozovatsky et al., 2005).

Records over the past 20 years show that the sediment in basin BII (see Fig. 2) usually remains consolidated at the bottom, with the lutocline at a depth of approximately $44 \mathrm{~m}$ (Casamitjana \& Roget, 1993, Colomer et al., 1998, Soler et al., 2005). Eventually, the subterranean springs in BII supply water to the lake at a rate comparable to those in BI. This is possible for high precipitation periods that recharge the aquifer, which in turn increases the pressure enough for incoming water to re-suspend the confined and consolidated sediment at the bottom of BII (Colomer et al., 2002). In this case the sediment migrates upward and initiates the fluidisation of the confined bed sediments. The initiation of the fluidisation usually coincides with the maximum mean monthly rainfall, which was about $250-350 \mathrm{~mm} /$ month. The rainfall, in turn, is associated with six main atmospheric circulation patterns among the 19 fundamental circulations that emerged in an earlier study that focused on significant rainfall days in Mediterranean Spain. They comprise a wide variety of flows over the Iberian Peninsula, with 
marked seasonal distributions and a clear distinction between Atlantic and western Mediterranean disturbances (Soler et al., 2005).

\section{THERMAL STRUCTURE, SEICHING AND BAROCLINIC CURRENTS}

The thermal structure of Lake Banyoles can be predicted by using a one dimensional lake model, like DYRESM, and inserting the inflow directly to the bottom of the water column (Casamitjana et al., 1993). Mean daily measurements of global radiation, downward long-wave radiation, wind speed, air temperature and water surface temperature were used to calculate a new equation for the non-radiative fluxes (Colomer et al., 1996). The predicted water temperature profiles are in good agreement with the observations in basin BI. In basins BIII and BIV the evolution of the temperature inversion in the hypolimnion, due to meromixis (Casamitjana \& Roget, 1986) and the rate of mixed layer deepening is also well predicted. The model shows how the groundwater intrusion greatly reduces the extent of summer stratification.

The first vertical modes of the internal seiches in Lake Banyoles were first calculated by Besalú et al. (1988) using a one-dimensional model. Although by that time high vertical modes had rarely been described in the literature, it was found later using a multi layer twodimensional model, that second vertical modes dominate the internal wave field in Lake Banyoles in spring (Roget, 1992) and their amplitudes were measured to be up to $2 \mathrm{~m}$. Furthermore, in an unexpected result, their period was not correlated to that of wind forcing (Roget et al., 1993a) as it was believed to always be the case for high vertical modes. Even considering the small fetch of the lake in this direction, due to the importance of the seabreeze regime (Roget et al., 1997), a persistent first vertical transversal mode was also found in the southern lobe. This transversal mode corresponds to the third horizontal for the southern lobe and coincides with the seventh of the whole lake. Coupling between oscillations of other density interfaces of the lake was also described in Roget (1992).

Because of the different thermal inertia of the two main lobes of the lake (with mean depths of 10 and $18 \mathrm{~m}$ ) and the different incoming heat flux through the underground sources located in them, it was found that in winter, denser water of the shallower northern lobe was plunging into the deepest lobe forming a bottom current, with velocities of up to $12 \mathrm{~cm} / \mathrm{s}$ observed in the central part of the lake. This current redistributes water between the two lobes and replaces the water of the northern lobe about every 5 days (otherwise its residence time would be about one year). Due to its magnitude (around 20000 $1 / \mathrm{s})$, it dominates the circulation of the lake (Roget et al., 1993b). This current was affected by the wind pattern and deflected towards the southwest due to the bottom topography, but also due to the Coriolis force. This is described in Roget \& Colomer (1996) where it is found that the cross slope of the isotherms agrees with the geostrophic balance.

\section{DYNAMICS OF THE HYDROTHERMAL PLUME}

The difference in temperature between the sediments in suspension and the hypolimnetic water immediately above them leads to the formation of a turbulent convective plume immediately above the lutocline (Colomer et al., 2001). The plume develops upwards until it reaches the level of neutral buoyancy, spreading laterally as gravity current. The estimated values of the Rossby number showed that rotation affects the plume development and that the plume develops to a maximum height limited by the strong temperature gradient of the seasonal thermocline. When there is no inflow through basin BII, a second stationary thermocline develops at a depth of around $22 \mathrm{~m}$ in this basin. Casamitjana \& Roget (1990b) found that this thermocline is only destroyed in the coldest months of January and February or whenever the fluidization of basin BII occurs. In this last case, the lutocline migrates upward, the secondary thermocline is 
destroyed and a new hydrothermal plume is formed in basin BII (Colomer et al., 2003).

As a major characteristic of convection from an isolated source, the plume entrains particles from the lutocline and carries a suspension of clay and silt particles upward with particle volume concentrations of $\sim 5-10 \mu \mathrm{L}^{-1}$. Because of the temperature inversion at the lutocline, the plume is negatively buoyant. As a result, it moves upward and in the absence of a thermal stratification background or in the presence of a weak one (as in the mixed lake period), it reaches the surface waters and then spreads laterally, with the consequent change of water quality caused by an increase of the suspended particle concentration (Serra et al., 2002a). It can be expected, then, that the suspended particles change the clarity of the water, which might imply a habitat constraint for fishes by limiting their feeding opportunities and other visual activities (Serra et al., 2002b).

Two-dimensional temperature and particle concentration measurements show the fate of the hydrothermal plume and its associated turbidity current and reveal its seasonal development (Serra et al., 2005). Silt particles transported by the plume have been used as tracers to determine the maximum and equilibrium heights of the plume. When the lake is stratified, the vertical transport of sediment is confined to the lake hypolimnion, since the thermocline limits the vertical propagation of the plume. In contrast, when the lake water column is mixed, the plume reaches the surface of the lake. The field measurements have been compared with models for thermal convection from finite isolated sources. Measurements of flow velocity at the source of the hydrothermal plume (i.e. the rim current velocity) indicate that cold hypolimnetic water is entrained by the plume. In the zone where the turbidity current develops, sedimentation rates measured from sediment traps vary between 10 and $25 \mathrm{~g} \mathrm{~m}^{-2} \mathrm{~d}^{-1}$, and result from continuous silt particle sedimentation from the turbidity current. Sedimentation rates in traps are higher for stations situated close to the source than for those further away $\left(<5 \mathrm{~g} \mathrm{~m}^{-2} \mathrm{~d}^{-1}\right)$. Moreover, the results demonstrate that double diffusive sedi- mentation from the turbidity current was dominant over grain-by-grain settling, causing a mixed distribution of sediments in the region where the turbidity current spreads. The deposition of silt particles could explain the occurrence of silt layers interbedded with biocalcarenites in the littoral zones of the lake and the stratigraphy identified by seismic profiles and cores taken from the lake floor. Therefore, all of the mentioned results demonstrate that the presence of the plume and the turbidity current affects the sedimentary records in the lake.

At the upper interface of the fluidised bed at the base of the plume, particle concentration and salinity (decreasing upwards) have the opposite effect of that of temperature (also decreasing upwards) on their contribution to the vertical density distribution, and the corresponding density ratio is a little bit greater than one. This condition, plus the fact that particle and salt diffusivities are lower than thermal diffusivity, makes the double-diffusive convection possible within a diffusive regime. At present, this is studied according to microstructure measurements recorded in basin BII, when a second thermocline at the entrance of the conic underground spring region exists, greatly isolating this region from the rest of the lake. In these circumstances, the upper interface of the fluidised bed is steplike for the three scalar fields, with well-mixed turbulent convective layers separated by diffusive interfaces (Sánchez \& Roget, 2005).

\section{ACKNOWLEDGMENTS}

We would like to thank the various collaborators involved in different ways in Lake Banyoles' research though the years: David Jou, Josep Enric Llebot, Josep Pararols, Marianna Soler, Ramon Julià, Xavier Vila, Esperança Gacia, Rafael Juanola, Jaume Piera, Romualdo Romero, John Alan Ross, Geoffrey Schladow, H. Joe Fernando, Xavier Sánchez, Javier Vidal, and Josep Pasqual. The authors are grateful to captain Joan Corominas for the outstanding help and support in the field campaigns in Lake Banyoles. Most of the funds were provided by 
the Catalan and Spanish Governments, through different agencies and projects.

\section{REFERENCES}

BESALÚ, E., J. MESTRES, P. VILARDELL, P. \& X. CASAMITJANA. 1988. Predicción de los períodos de las secas externas y internas del Lago de Banyoles. Scientia Gerundensis, 14, 137-147.

CASAMITJANA, X. 1989. Physical dynamics of the basin springs in Lake Banyoles. (in catalan) Ph.D. Universitat Autònoma de Barcelona, Spain. 227 pp

CASAMITJANA, X. \& E. ROGET. 1986. Fenòmens de meromixis a l'estany de Banyoles. Scientia gerundesis, 12: 151-161.

CASAMITJANA, X., E. ROGET, D. JOU \& J. E. LLEBOT. 1988. Effect of the suspended sediment in the heating of Lake Banyoles. Journal of Geophysical Research, 93, (C8): 9332-36.

CASAMITJANA, X. \& E. ROGET. 1990a. Characterization of the natural fluidized beds of Lake Banyoles. In: Fluidization and fluid particle systems. J. Casals \& J. Arnaldos (eds.): 189-196, UPC, Barcelona.

CASAMITJANA, X. \& E. ROGET. 1990b. The thermal structure of Lake Banyoles, Verh. Internat. Verein. Limnol., 24: 89 - 91.

CASAMITJANA, X. \& E. ROGET. 1993. Resuspension of sediments by focussed groundwater. Limnol. Oceanogr., 38(3): 643-656

CASAMITJANA, X., E. ROGET \& G. SCHLADOW. 1993. The seasonal cycle of a groundwater dominated lake. Journal of Hydraulic Research, 31(3): 293-306.

CASAMITJANA, X., J. COLOMER, E. ROGET \& T. SERRA. 1996. On the presence of aggregates in the basins of Lake Banyoles. Geophysical Research Letters, 23 (20):2737-2740.

CASAMITJANA, X., COLOMER, J. \& H. J. S. FERNANDO. 2000. Fluidization of sediments in a conical basin by subterranean springs: relevance to Lake Banyoles. Aquatic Sciences, 62: 79-90.

CANALS, M., H. GOT, R. JULIÀ \& J. SERRA. 1990. Solution-collapse depressions and suspensates in the limnocrenic lake of Banyoles (NE Spain). Earth Surf. Proc. Land., 15: 243- 254.

COLOMER, J. \& H. J. S. FERNANDO. 1996. Resuspension of particle bed by round vertical jet. Journal of Environmental Engineering, 122, (9):864-869.
COLOMER, J., E. ROGET \& X. CASAMITJANA. 1996. Daytime heat balance for estimating nonradiative fluxes of Lake Banyoles. Hydrological processes, 10: 721-726.

COLOMER, J., J. A. ROSS \& X. CASAMITJANA. 1998. Sediment entrainment in karst basins. Aquatic Sciences, 60: 338-358.

COLOMER, J, T. SERRA, J. PIERA, E. ROGET \& X. CASAMITJANA. 2001. Observations of a hydrothermal plume in a karstic lake. Limno. Oceanogr., 46 (1):197-203.

COLOMER, J., T. SERRA, M. SOLER \& X. CASAMITJANA. 2002. Sediment fluidization in a lake caused by monthly rainfalls. Geophysical Research Letters, 29 (8): 1260.

COLOMER, J., T. SERRA, M. SOLER \& X. CASAMITJANA. 2003. Hydrothermal plumes trapped by thermal stratification. Geophysical Research Letters, 30 (21): 2092.

GUERRERO, R., C. ABELLÀ, C. \& R. M. MIRACLE. 1978. Spatial and temporal distribution of bacteria in meromictic kastic lake basin: relationship with physicochemical parameters and zooplankton. Verh. Internat. Verein. Limnol., 20:2264-2271.

LOZOVASTKY, I., E. ROGET, E. \& H. J. S. FERNANDO. 2005 Mixing in Shallow Waters: Measurements, Processing, and Applications. Journal of Ocean. University of China, (in press).

MARGALEF, R. 1946. Materiales para el estudio del lago de Banyoles. Publ. Inst. Biol. Aplicada. Barcelona. 1: 27-28.

MASCARÓ, J. M. 1914. Topografía médica de Banyoles. Imp y Lib. D. Torres. Girona. 403 pp.

MORENO-AMICH, R. \& E. GARCÍA BERTHOU. 1989. A new bathymetric map based on echosounding and morphometrical characterization of the Lake of Banyoles. Hydrobiologia, 185: 83-90.

MUÑIZ, M. A. 2000. Analysis of microstructure and turbulence data in a convective plume (in Catalan). Master Thesis. University of Girona. 54 pp.

PLANAS, D. 1973. Composición, ciclo y productividad del fitoplancton del lago de Banyoles. Oecologia Aquatica, 1:3-106.

RIERADEVALL, M. \& N. PRAT. 1991. Benthic fauna of Banyoles Lake (NE Spain). Verh. Internat. Verein. Limnol., 24: 1020-1023.

ROGET, E. 1987. Study of the incoming flows in the basins of Lake Banyoles (in catalan). Master Thesis. Universitat Autònoma de Barcelona, Col-legi Universitari de Girona, 81 pp. 
ROGET, E. \& X. CASAMITJANA. 1987. Comportament dels llits fluïditzats naturals a l'estany de Banyoles. Scientia Gerundensis, 13:187-199.

ROGET, E. 1992. Internal seiches and baroclinic currents in Lake Banyoles (in catalan). Ph.D. Universitat Autònoma de Barcelona, Bellaterra, Spain. 287 pp.

ROGET, E., G. SALVADÉ, F. ZAMOBINI \& J. E. LLEBOT. 1993a. Internal waves in a small lake with a thick metalimnion. Verh. Internat. Verein. Limnol., 25, 91-99.

ROGET, E., J. COLOMER, X. CASAMITJANA \& J. E. LLEBOT. 1993b. Bottom currents induced by baroclinic forcing in Lake Banyoles (Spain). Aquatic Sciences, 55(3): 206-227.

ROGET, E., X. CASAMITJANA \& J. E. LLEBOT. 1994. Calculation of the flow into a lake through the underground springs with suspensions. Netherlands Journal of Aquatic Ecology, 28: 135-141.

ROGET, E. \& J. COLOMER. 1996. Flow characteristics of a gravity current induced by differential cooling in a small lake. Aquatic Sciences 58(4): 367-377.

ROGET, E., G. SALVADÉ \& F. ZAMBONI. 1997. Internal seiche climatology in a small lake where transversal and second vertical modes are usually observed. Limnol. Oceanogr., 4(42): 663-673.

ROGET, E., I. LOZOVATSKY, X. SÁNCHEZ \& M. FIGUEROA. 2005. Microstructure measurements in natural waters. Methodology and applications. Progress in Oceanography, (in press).

SÁNCHEZ, X. 2001. Fitting technique to Batchelor spectra; a new methodological approximation (in catalan). Master Thesis. Universitat de Girona, 54 pp.
SÁNCHEZ, X. \& E. ROGET. 2005 Convective dynamics above the upper interface of a warm and salty fluidized bed located at the bottom of a lake. In: Physical Processes in natural Waters, A. Folkard \& I. Joes (eds).: 273-279. Department of Geography, Lancaster University, U. K.

SANZ, M. 1985. Estudi hidrogeològic de la regió Banyoles-Garrotxa. Quadern del Centre d'Estudis Comarcals de Banyoles, 2: 171-210.

SERRA, T., J. COLOMER, L. ZAMORA, R. MORENO-AMICH \& X. CASAMITJANA, 2002a.. Seasonal development of a turbid hydrothermal plume in a lake. Water Research, 36 (11): 2753-2760.

SERRA, T., J. COLOMER, E. GACIA, M. SOLER \& X. CASAMITJANA. 2002b. Effects of a turbid hydrothermal plume on the sedimentation rates in a karstic lake. Geophys. Res. Lett., 29 (21): 2029.

SERRA, T., J. COLOMER, A. STIPS, F. MOHLENBERG \& X. CASAMITJANA. 2003. The role of advection and turbulent mixing in the vertical distribution of phytoplankton Estuarine, Coastal and Shelf Science, 56: 53-62.

SERRA, T., J. COLOMER, M. SOLER, R. JULIÀ \& X. CASAMITJANA. 2005. Behaviour and dynamics of a hydrothermal plume in Lake Banyoles, Catalonia, NE Spain. Sedimentology, 52 (4): 795-808.

ROMERO, R., M. SOLER, T. SERRA \& J. COLOMER. 2005. Turbidity variability in Lake Banyoles (Girona, Spain): Relationship with anomalous rainfall and atmospheric synoptic flow pattern. Geophysical Research Abstracts, 7: 02905.

VIDAL-PARDAL, J. 1925. L'estany de Banyoles. Girona. 154. 